\title{
ARTIKELEN
}

\section{Voorontwerp Wet verzekerdeninvloed: een nieuwe vorm van medezeggenschap}

\author{
Mr. dr. A.G.H. Klaassen*
}

\section{Inleiding}

Twintig jaar na de invoering van de Wet medezeggenschap cliënten zorginstellingen (Wmcz), waarin de medezeggenschap van cliënten van zorginstellingen is geregeld, ziet het ernaar uit dat ook verzekerden invloed krijgen op de besluitvorming van de raden van bestuur van zorgverzekeraars. Begin juli 2016 is het Voorontwerp van de Wet verzekerdeninvloed $^{1}$ (Voorontwerp) ter consultatie gepubliceerd door de minister van Volksgezondheid, Welzijn en Sport (VWS). ${ }^{2}$ Een versterkte positie van de verzekerden is in het belang van de maatschappelijke verankering van het zorgstelsel, zo staat in de Concept-MvT. ${ }^{3}$ De invoering van de wet zal leiden tot aanpassing van de Zorgverzekeringswet (Zvw). De artikelen 28a, 28b en 28c zullen aan deze wet worden toegevoegd.

De vraag is: wordt de positie van verzekerden met deze wet voldoende versterkt of zijn er nog verbeteringen mogelijk?

De opzet is als volgt. Paragraaf 2 gaat over de noodzaak om de invloed van verzekerden te versterken. In paragraaf 3 worden de huidige eisen behandeld die gesteld worden aan de invloed van verzekerden en de bestaande knelpunten in de praktijk. De bepalingen van het Voorontwerp worden in paragraaf 4 beschreven. In paragraaf 5 wordt ingegaan op de wijze van toezicht en handhaving van de nieuwe Zvw-bepalingen. Tot slot bevat paragraaf 6 de conclusie.

\section{Zorgverzekeringsstelsel: noodzaak tot versterking invloed verzekerden}

In 2014 heeft de Raad voor de Volksgezondheid (RVZ, nu: RVS ${ }^{4}$ ) in haar rapport 'De stem van de verzekerden' voorstellen gedaan om de positie van de verzekerden in het zorginkoopproces te verankeren. ${ }^{5}$ Zorgverzekeraars hebben sinds 2006, het jaar van de invoering

* Ageeth Klaassen is universitair docent ondernemingsrecht. Zij doceert het vak Organisatie en bestuur van de zorg in de master Recht van de gezondheidszorg aan de Erasmus Universiteit Rotterdam; zij is lid van raden van toezicht in de eerstelijnsgezondheidszorg.

1 De volledige titel luidt: 'Wijziging van de Zorgverzekeringswet in verband met versterking van de invloed van verzekerden op de zorgverzekeraar (verzekerdeninvloed)'.

2 www.internetconsultatie.nl/wijziging_van_de_zvw_ivm_met_versterking_van_de_invloed_van_ verzekerden_op_de_zorgverzekeraar. De sluitingsdatum is 7 augustus 2016. Een consultatietermijn van een maand lijkt mij erg kort in de zomerperiode.

3 Concept-MvT, p. 1.

4 Raad voor Volksgezondheid en Samenleving.

5 RVZ, 'De stem van de verzekerden', Den Haag 2014. 
van het nieuwe zorgverzekeringsstelsel, als private partijen steeds grotere verantwoordelijkheden gekregen bij het borgen van publieke belangen. Zorgverzekeraars hebben een duidelijke rol gekregen als zorginkoper. ${ }^{6}$ De vraag is of de legitimiteit van deze zorginkoop- en zorgregisseursrol vanuit het perspectief van de verzekerde voldoende is. ${ }^{7}$

$\mathrm{Na}$ het verschijnen van dit rapport hebben Kamerleden in verschillende moties opgeroepen om de invloed van verzekerden op het beleid van zorgverzekeraars te versterken ten behoeve van het evenwicht in het zorgstelsel. ${ }^{8}$ Het Voorontwerp geeft uitvoering aan de voorstellen van RVZ en deze moties.

De regering acht het van belang dat het door zorgverzekeraars gevoerde beleid aansluit bij de wensen van de verzekerden. Het gaat met name om invloed op het zorginkoopbeleid. Momenteel ontbreken hiervoor de wettelijke randvoorwaarden, aldus de Concept-MvT. ${ }^{9}$

\section{Huidige regels en praktijk}

Naar huidig recht dienen de statuten van zorgverzekeraars op grond van artikel 28 lid 1 onderdeel b Zvw waarborgen te bieden voor een redelijke mate van invloed van de verzekerden op het beleid. ${ }^{10}$ Momenteel wordt dit in de Zvw niet nader omschreven. In lid 2 van artikel $28 \mathrm{Zvw}$ staat dat bij algemene maatregel van bestuur (AMvB) regels kunnen worden gesteld over de mate van invloed die verzekerden ten minste op het beleid van een zorgverzekeraar dienen te hebben. Van deze mogelijkheid is tot nu toe geen gebruik gemaakt. ${ }^{11}$ Dit betekent niet dat aan artikel $28 \mathrm{Zvw}$ in de praktijk geen gevolg wordt gegeven. Op grond van het Informatiemodel uitvoeringsverslag Zvw 2015 dienen zorgverzekeraars zich te verantwoorden aan de Nederlandse Zorgautoriteit (NZa) over de wijze waarop in de praktijk invulling wordt gegeven aan de invloed van verzekerden. ${ }^{12}$

De vraag is hoe zorgverzekeraars in de praktijk invloed geven aan hun verzekerden. Dit kan op verschillende wijzen. Hierbij is het gebruikelijk onderscheid te maken tussen formele en informele invloed.

6 RVZ 2014, p. 7. Dit geldt niet als een verzekeraar ervoor kiest alleen restitutieverzekeringen aan te bieden.

7 Zie hierover RVZ 2014, p. 16 e.v.

8 De inhoud van de motie Bouwmeester/Dik-Faber was aanleiding voor de minister van VWS om het Instituut Beleid \& Management Gezondheidszorg (IBMG) te laten adviseren over hoe de invloed van verzekerden kan worden vormgegeven. IBMG heeft hiertoe zes principes geformuleerd. Zie H. van de Bovenkamp, P. Meurs \& M. de Lint, Gevarieerde medezeggenschap in zorginstellingen en bij zorgverzekeraars, Instituut Beleid \& Management Gezondheidszorg (IBMG), Erasmus Universiteit Rotterdam mei 2016, p. 31.

9 Concept-MvT, p. 1. De diverse stappen die door zorgverzekeraars zijn gezet worden kennelijk niet voldoende geacht. Zie voor Kern-gezond, het actieplan van Zorgverzekeraars Nederland (vereniging van zorgverzekeraars) uit april 2015, https://www.zn.nl/336986126/Document?documentregistrationid=339283579.

10 De bedoeling van deze bepaling was oorspronkelijk dat betrokkenheid van verzekerden bij het beleid van de zorgverzekeraar het sociale karakter van de zorgverzekering zou waarborgen. Zie Concept-MvT, p. 1.

11 Concept-MvT, p. 2.

12 Zie paragraaf 3.2 van het Informatiemodel uitvoeringsverslag Zvw 2015, https://www.nza.nl/101550/ 101553/101556/11716/Informatiemodel_uitvoeringsverslag_Zvw_2015.pdf (met oplevering in 2016). Zie art. $38 \mathrm{Zvw}$ en art. 3.1 Regeling Zorgverzekering. Zie ook § 2.1.20 Gedragscode Goed Zorgverzekeraarschap. 


\subsection{Formele invloed: ledenraden}

In Nederland zijn er negen zorgverzekeraars. ${ }^{13}$ De zorgverzekeraars maken vaak deel uit van een concern. De moedermaatschappij kan, naast een OWM of nv, ook een coöperatie of bv zijn. Bij de betreffende bv's is een vereniging de (grootste) aandeelhouder. ${ }^{14}$ Dit betekent dat binnen de verzekeringsconcerns, met uitzondering van ASR, zeggenschap van verzekerden plaatsvindt in een ledenraad. ${ }^{15}$ Ledenraden hebben op grond van Boek $2 \mathrm{BW}$ onder meer de volgende bevoegdheden: het benoemen van de leden van de raad van bestuur en de raad van commissarissen, statutenwijziging, ontbinding en goedkeuring van het jaarverslag of vaststelling van de jaarrekening. ${ }^{16}$

Een knelpunt is dat ledenraden niet altijd onafhankelijk zijn (door onder andere de rol van de raad van bestuur en raad van commissarissen bij de selectieprocedure van de leden). Daarnaast voelen leden zich niet altijd deskundig en vormen zij geen goede afspiegeling van de verzekerdenpopulatie. ${ }^{17}$ Verzekerden geven aan dat zij vooral over inhoudelijke onderwerpen met betrekking tot de zorgverzekering willen meepraten. ${ }^{18}$ De huidige bevoegdheden van de ledenraad zijn onvoldoende voor deze gewenste invloed.

\subsection{Informele invloed ${ }^{19}$}

Naast de formele invloed van ledenraden, maken zorgverzekeraars in de praktijk veel gebruik van klantenpanels of verzekerdenraden. ${ }^{20}$ Een klantenpanel is een vaste groep van verzekerden, waar de zorgverzekeraar vragen aan kan stellen en de dialoog mee kan aangaan. ${ }^{21}$ Een verzekerdenraad, naast een ledenraad, vervult vooral de rol van klankbord voor de raad van bestuur. Een aantal zorgverzekeraars organiseert regiobijeenkomsten om verzekerden te betrekken bij het beleid. Als moderne alternatieven kan gedacht worden aan digitale communities en crowdsourcing. ${ }^{22}$ Van deze laatste mogelijkheden maken zorgverzekeraars beperkt gebruik. ${ }^{23}$

13 Achmea, VGZ, CZ, Menzis, DSW, ONVZ, Zorg en Zekerheid, ASR en Eno.

14 Achmea en ONVZ.

15 Op grond van de polisvoorwaarden van hun zorgverzekering zijn verzekerden lid van de OWM, coöperatie of vereniging binnen het concern (zie Concept-MvT, p. 2). In de statuten van zorgverzekeraars staat dat de zeggenschap van de algemene ledenvergadering overgaat naar de ledenraad. Deze ledenraad bestaat uit afgevaardigden die door en uit de leden worden gekozen. De statuten bepalen de wijze van verkiezing van de afvaardigden van de ledenraad (art. 2:39 BW) en kunnen drempels opwerpen om afgevaardigde te worden. De ledenraad van de Vereniging Achmea bestaat bijvoorbeeld uit leden die door de stemgerechtigde leden worden benoemd. Om stemgerechtigd lid te worden moet daartoe een schriftelijk verzoek worden gedaan bij het bestuur. Overigens bestaat de ledenraad van Vereniging Achmea uit maximaal honderd leden.

16 Art. 2:37 BW, art. 2:57a BW, art. 2:42 lid 1 en lid 4 BW, art. 2:48/49/58 BW. Zie voor (andere) opsommingen, Concept-MvT, p. 2 en RVZ 2014, p. 26.

17 Concept-MvT, p. 3-4. Zie ook RVZ 2014, p. 27 en 39.

$18 \mathrm{NZa}$, 'Thematisch onderzoek Verzekerdeninvloed Zorgverzekeringswet', mei 2007, p. 29. Zie ook RVZ 2014, p. 37 en 39.

19 Zie Concept-MvT, p. 3, NZa 2007, p. 15 e.v., RVZ 2014, p. 30 e.v.

20 Een verzekerdenraad heeft niet dezelfde formele wettelijke en statutaire bevoegdheden als een ledenraad. Naast een ledenraad heeft Achmea ook verzekerdenraden, zie Achmea jaarverslag 2015, p. 29.

21 RVZ 2014, p. 31

22 Onder crowdsourcing verstaat RVZ het gebruikmaken door een organisatie van grote, niet-gespecificeerde groepen individuen voor consultancy, innovatie, beleidsvorming en onderzoek. RVZ 2014, p. 32. 
Een knelpunt is dat verzekerden niet altijd op de hoogte zijn van de mogelijkheden die zij hebben om mee te kunnen praten over het beleid van de zorgverzekeraar. ${ }^{24}$ Meer transparantie over de beschikbare instrumenten om invloed uit te oefenen is gewenst.

\section{Voorontwerp}

De Wet verzekerdeninvloed zorgt voor medezeggenschap op twee niveaus. Er moet inspraak komen voor alle verzekerden (informele invloed) en er komt een permanente verzekerdenvertegenwoordiging als 'hoedster' van verzekerdeninspraak waaraan een tweetal rechten wordt toegekend (formele invloed). ${ }^{25}$ Deze permanente vertegenwoordiging wordt vereist op grond van artikel 28 lid 2 Zvw (nieuw). Ik kom hierop terug in paragraaf 4.2. Deze vormen van medezeggenschap sluiten aan bij de rapporten van RVZ en IBMG om zowel de informele als de formele invloed te versterken. ${ }^{26}$

\section{- Wet of $A M v B$ ?}

Oorspronkelijk wilde de minister van VWS, zoals is aangekondigd in de brief 'Kwaliteit loont', ${ }^{27}$ de invloed van verzekerden op het beleid van zorgverzekeraars vergroten door middel van een AMvB. ${ }^{28}$ De Tweede Kamer heeft in het debat over deze brief nadrukkelijk om wetgeving gevraagd. ${ }^{29} \mathrm{Er}$ is voor gekozen om de Zvw aan te passen. Hoewel de artikelen 28a, 28 en 28c Zvw (nieuw) een uitwerking zijn van art. 28 lid 1 onderdeel b Zvw, wordt in de Concept-MvT niet nader toegelicht wat de voor- en nadelen van deze keuze zijn. Wat zijn de beweegredenen om niet voor een zelfstandige wet te kiezen, zoals de Wet op de ondernemingsraden (WOR), waarin de medezeggenschap van werknemers is geregeld, en de Wmcz?

\section{- Meer Wmcz of WOR?}

De opzet van de Wet verzekerdeninvloed lijkt meer op de Wmcz dan op de WOR. Bij de bepalingen in het Voorontwerp is, net zoals bij de Wmcz, sprake van wettelijk geconditioneerde zelfregulering. ${ }^{30}$ Er wordt ruimte gelaten aan zorgverzekeraars en de (vertegenwoordiging van) verzekerden om hieraan gezamenlijk invulling te geven. Het is (alleen) noodzakelijk het wettelijk kader aan te scherpen met minimumeisen voor de invloed van verzekerden op het beleid van de zorgverzekeraar, zo staat in de Concept-MvT. ${ }^{31}$

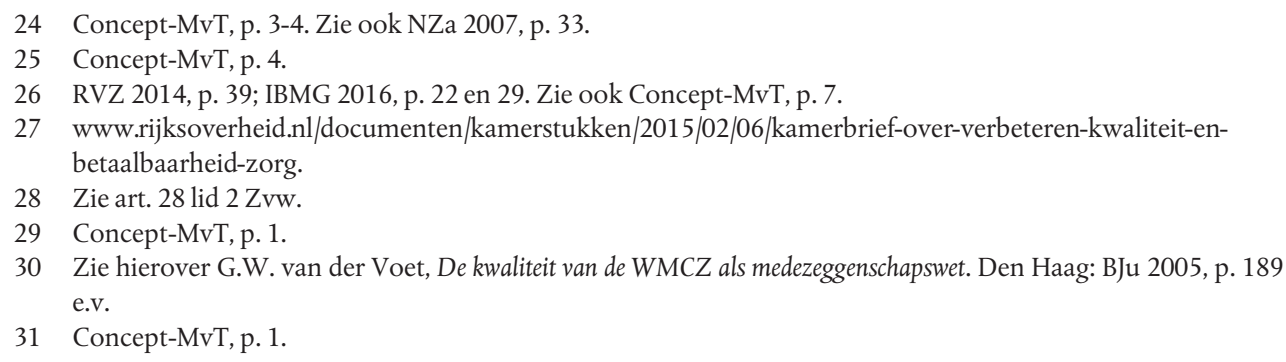


Wie thuis is in de Wmcz zal een aantal bepalingen uit dit Voorontwerp herkennen. Op meerdere wettelijke onderdelen zullen dit Voorontwerp en de (toekomstige aanpaste ${ }^{32}$ ) Wmcz van elkaar verschillen. In de ogen van de minister van VWS is de relatie tussen verzekerden en zorgverzekeraar van andere aard dan die tussen cliënten en zorginstellingen. De aard van de relatie verschilt door de mate van afhankelijkheid en de omvang van de populatie. ${ }^{33}$

Een aantal vergelijkbare bepalingen in het Voorontwerp wordt anders geformuleerd dan in de Wmcz en/of de WOR. In de Concept-MvT wordt niet nader uitgelegd waarom wel of niet wordt aangeknoopt bij bepalingen uit de Wmcz of uit de WOR. Het zou bijdragen aan het begrip en/of doel van de bepalingen uit het Voorontwerp als in de MvT wordt uitgelegd met welke reden wordt afgeweken van deze medezeggenschapswetten.

\subsection{Inspraakregeling}

Op grond van artikel 28a lid $1 \mathrm{Zvw}$ (nieuw) dient de zorgverzekeraar zijn verzekerden in de gelegenheid te stellen inspraak uit te oefenen op zijn beleid. Hierdoor moet de dialoog tussen verzekerden en zorgverzekeraars bewerkstelligd worden bij de totstandkoming van het beleid. ${ }^{34}$ Dit kan volgens de Concept-MvT zowel inspraak zijn op bestaand beleid als op beleidsvoornemens van de zorgverzekeraars. ${ }^{35}$ Door de inbreng van verzekerden zal het beleid beter aansluiten bij de wensen van verzekerden, aldus de Concept-MvT. De gedachte is dat dit de kwaliteit van de ingekochte zorg, de inhoud van de zorgverzekeringen die de zorgverzekeraar aanbiedt en de dienstverlening van de zorgverzekeraar ten goede komt. ${ }^{36}$

\section{- Hoofdlijnen zorginkoopbeleid}

De zorgverzekeraar stelt een schriftelijke regeling vast, zo staat in artikel 28a lid 2 Zvw (nieuw), waarin wordt bepaald op welke onderdelen van het beleid de inspraak betrekking heeft. De inspraak heeft in elk geval betrekking op de hoofdlijnen ${ }^{37}$ van het zorginkoopbeleid van de zorgverzekeraar, zo staat in datzelfde lid 2 . Hieronder valt volgens de ConceptMvT: het contracteerbeleid van de zorgverzekeraar, de inhoud van de gecontracteerde zorg, de belangrijkste voorwaarden waaronder contractering plaatsvindt, het beleid met betrekking tot het inkoopproces en bepaalde kwaliteitseisen van zorg (bijvoorbeeld maximale reisafstand tot een zorgaanbieder, openingstijden, bereikbaarheid). ${ }^{38}$ Inspraak op onderdelen van het (algemene) beleid behoort ook tot de mogelijkheden, zo staat in de Concept-MvT, maar dit moet dan worden opgenomen in de inspraakregeling. Volgens de

Eind september 2016 is het Voorontwerp van de nieuwe Wmcz gepubliceerd ter consultatie, zie www. internetconsultatie.nl/wijziging_wet_medezeggenschap_clienten_zorgsector. Hiervoor geldt een consultatietermijn van zes weken.

Kamerstukken II 2015/16, 31765, 209, p. 3.

34 Concept-MvT, p. 5.

35 Concept-MvT, p. 11. Dit moet wel gebeuren op een tijdstip dat nog wezenlijke wijzigingen in het voorgenomen beleid kunnen worden aangebracht.

36 Concept-MvT, p. 1.

37 Het is derhalve niet voorgeschreven dat de inspraak zich uitstrekt over alle details van de zorginkoop of over het gehele jaarlijks vast te stellen en te publiceren inkoopbeleid, aldus de Concept-MvT, p. 11. Dit is wel mogelijk als dit wordt vastgelegd in inspraakregeling. 
Concept-MvT moet worden gedacht aan het communicatiebeleid, het aantal labels, het polisaanbod, de regionale organisatie van zorg en het marketingbeleid. ${ }^{39}$

- Transparantie en verantwoording

Verplichte onderdelen van de schriftelijke regeling zijn, volgens artikel 28a lid 2 Zvw (nieuw), (i) de wijze waarop verzekerden inspraak krijgen, (ii) op welke wijze de verzekerden informatie ontvangen over de resultaten van de inspraak, (iii) alsmede over wat met de resultaten is gedaan.

Verzekerden kunnen alleen betrokken worden als zij er tijdig van op de hoogte zijn dat zij hun mening en hun wensen kunnen inbrengen, zo is de opvatting. Zorgverzekeraars moeten daarom transparant maken met welke instrumenten verzekerden inspraak kunnen uitoefenen op het beleid. ${ }^{40}$ Genoemde voorbeelden in de Concept-MvT zijn het organiseren van regiobijeenkomsten met verzekerden, het lanceren van digitale platforms, inzet van klantenpanels en sociale media, uitzetten van enquêtes en het opzetten van 'virtual communities'. ${ }^{41}$

De bekendmaking van de resultaten heeft als doel inzichtelijk te maken welk effect de inspraak heeft gehad. Deze transparantie is van belang, zo staat in de Concept-MvT, omdat de verzekerde hierdoor ook gesprekspartner wordt van de zorgverzekeraar over de wijze waarop met de meningen en wensen van verzekerden wordt omgegaan. ${ }^{42}$ Met deze terugkoppeling kan de zorgverzekeraar laten zien dat de meningen en wensen van zijn verzekerden er daadwerkelijk toe doen. ${ }^{43}$ Van belang is dat zorgverzekeraars hun verzekerden informeren over het 'waarom' achter het beleid en uitleggen waarom aan de inbreng van bepaalde (groepen van) verzekerden geen gehoor wordt gegeven, aldus de Concept-MvT. ${ }^{44}$ Het Voorontwerp schrijft niet voor via welke kanalen zorgverzekeraars hun verzekerden moeten informeren. ${ }^{45}$

Daarnaast maakt de zorgverzekeraar de inhoud van de inspraakregeling bekend aan zijn verzekerden, aldus artikel 28a lid 4 Zvw (nieuw). In de Concept-MvT staat dat indien de zorgverzekeraar de regeling publiceert op een gemakkelijk vindbare en logische plek op zijn website, ook potentiële verzekerden deze informatie kunnen betrekken bij hun keuze voor een zorgverzekering. ${ }^{46}$

\section{- Instemming}

Artikel 28a Zvw (nieuw) stelt volgens de Concept-MvT bewust geen verdere eisen aan de inspraakregeling. De permanente vertegenwoordiging van verzekerden krijgt hierin name-

\footnotetext{
39 Concept-MvT, p. 5.

40 Concept-MvT, p. 5.

41 Concept-MvT, p. 12.

42 Concept-MvT, p. 5.

43 Concept-MvT, p. 12.

44 Concept-MvT, p. 5. Dit is onder meer van belang omdat de preferenties van de verschillende verzekerden zullen verschillen: verzekerden zullen niet altijd dezelfde belangen hebben. Bij de totstandkoming van het beleid zal dan ook een afweging moeten worden gemaakt tussen de diverse belangen en inzichtelijk moeten worden teruggekoppeld naar de verzekerden hoe hiermee rekening is gehouden.

45 De middelen (voor informatie) moeten worden opgenomen in de inspraakregeling.

46 Concept-MvT, p. 5.
} 
lijk een essentiële rol: voor het vaststellen, wijzigen of intrekken van de inspraakregeling is de instemming van de permanente vertegenwoordiging ${ }^{47}$ vereist, zo staat in lid 3 van artikel 28a Zvw (nieuw). ${ }^{48}$ Zie hierover paragraaf 4.2.2.

Met deze inspraakregeling wordt de invloed van de verzekerden versterkt. Met de voorwaarden die daaraan worden gesteld wordt in mijn ogen de vrijblijvendheid om invloed aan verzekerden te geven weggenomen. De informele invloed wordt op deze wijze (gedeeltelijk) geformaliseerd. Dit sluit aan bij de aanbeveling van IBMG dat wetgeving 'niet te veel dichttimmert en inzet op vormvereisten'. ${ }^{49}$

In welke mate de invloed van de verzekerden versterkt wordt, zal afhangen van hoe de inspraakregeling nader wordt ingevuld. In elk geval hebben verzekerden door het instemmingsrecht van de permanente vertegenwoordiging een stevige vinger in de pap bij de invulling van de inspraakregeling. Voordeel van de gekozen wettelijke opzet van een inspraakregeling is dat er ruimte is voor verschillende vormen van inspraak al naar gelang de wensen van de verzekerden en de zorgverzekeraar. Door inspraak te geven aan alle verzekerden, en niet alleen een vertegenwoordiging van verzekerden, kan een grote groep worden gehoord. ${ }^{50}$

\subsection{Permanente vertegenwoordiging}

Op grond van lid 2 van artikel $28 \mathrm{Zvw}$ (nieuw) dient een zorgverzekeraar, zoals hiervoor genoemd, te beschikken over een permanente vertegenwoordiging. In dit lid staat dat de waarborgen voor een redelijke mate van invloed van verzekerden op het beleid in ieder geval bestaan uit het toekennen van het adviesrecht en het al genoemde instemmingsrecht aan een permanente vertegenwoordiging. ${ }^{51}$

Een voor de hand liggende vraag is: wat is precies de permanente vertegenwoordiging in de Wet verzekerdeninvloed? Uit de Concept-MvT blijkt dat de permanente vertegenwoordiging zich onderscheidt van min of meer incidentele vormen van vertegenwoordiging, zoals een klantenpanel. Zij dient de rol van klankbord voor de raad van bestuur te gaan vervullen. Het is niet de bedoeling dat de permanente vertegenwoordiging de rol van andere organen, zoals de raad van commissarissen of de ondernemingsraad, gaat doorkruisen of een klachtenbureau gaat worden. ${ }^{52}$

Een zorgverzekeraar hoeft geen afzonderlijke medezeggenschapsraad in te stellen. Om organisatorische wijzigingen die in de praktijk onvoldoende toevoegen kan de zorgverzekeraar ervoor kiezen deze rechten (van de permanente vertegenwoordiging) toe te kennen aan een al bestaande ledenraad (in de zin van Boek 2 BW) of een ingestelde verzekerdenraad. ${ }^{53}$ Het wordt aan de zorgverzekeraar zelf gelaten of de wettelijke bevoegdheden worden toegekend aan een vertegenwoordiging op het niveau van de zorgverzekeraar of hoger

Zie paragraaf 4.2

Concept-MvT, p. 12.

IBMG 2016, p. 31.

Zie voor een aantal principes voor de vormgeving van medezeggenschap: IBMG 2016, p. 30.

Art. 28a lid 3 en art. 28c lid $1 \mathrm{Zvw}$ (nieuw). Zie paragraaf 4.2.2.

Concept-MvT, p. 7 en 11.

Concept-MvT, p. 9 en p. 11. 
in de organisatie, op concernniveau. ${ }^{54}$ Daarbij is wel een bezwaar dat wanneer een ledenraad (in de zin van Boek 2 BW) de rechten krijgt van de permanente vertegenwoordiging, deze ledenraad moet voldoen aan de eisen van artikel 28b Zvw (nieuw). ${ }^{55}$ In de praktijk zal de benaming 'permanente vertegenwoordiging' niet vaak gebruikt gaan worden, zo is mijn verwachting. Overigens kunnen de ondernemingsraad en de cliëntenraad ook met een andere benaming aangeduid worden.

\subsubsection{Samenstelling en functioneren}

Artikel 28b Zvw (nieuw) gaat over de samenstelling en het functioneren van de permanente vertegenwoordiging en de waarborgen daarvoor. Dit wordt nader uitgewerkt in de verschillende leden van het artikel.

\section{- $\quad$ Samenstelling}

De permanente vertegenwoordiging kan volgens artikel 28b lid 1 Zvw (nieuw) uitsluitend bestaan uit representatieve vertegenwoordigers van de verzekerden bij de zorgverzekeraar. ${ }^{56}$ Volgens de Concept-MvT dient de vertegenwoordiging een juiste afspiegeling te vormen van de verzekerdenpopulatie. Bij de samenstelling van de permanente vertegenwoordiging dient rekening te worden gehouden met de leeftijd van vertegenwoordigers, opleiding, achtergrond, mate van zorggebruik en zorgbehoefte en opgedane ervaringen met zorg. ${ }^{57}$ Om de beschikbaarheid van kandidaten ${ }^{58}$ zo groot mogelijk te maken, is waarschijnlijk (mede) de volgende randvoorwaarde gesteld.

\section{- Openbare vacature}

De zorgverzekeraar draagt er zorg voor dat een vacature van de (permanente) vertegenwoordiging openbaar wordt gemaakt, zo staat in artikel 28b lid 2 onderdeel a Zvw (nieuw). Bekendheid kan aan openstaande vacatures worden gegeven via publicatie in een dagblad of op een zichtbare plek op de webpagina van de zorgverzekeraar, aldus de Concept-MvT. ${ }^{59}$ In elk geval mogen de leden van de permanente vertegenwoordiging niet worden geworven door middel van een gerichte persoonlijke benadering door de raad van bestuur. ${ }^{60}$ Transparant moet zijn welke kwaliteiten worden gezocht en de (andere) eisen

54 Concept-MvT, p. 5. Zorgverzekeraars hoeven derhalve niet allemaal een eigen vertegenwoordiging van verzekerden in het leven te roepen (Concept-MvT, p. 9).

55 Zie paragraaf 4.2.1 (Samenstelling). Voor zorgverzekeraars die deel uitmaken van een groter verzekeringsconcern met meerdere soorten verzekeringen zal de representativiteitseis niet eenvoudig liggen. In de ConceptMvT (p. 12-13) wordt erop gewezen dat een permanente vertegenwoordiging die naast de vertegenwoordigers van zorgverzekerden tevens bestaat uit vertegenwoordigers van verzekerden voor andere risico's (bijvoorbeeld rechtsbijstand of autoschade) niet kan worden geacht representatief te zijn voor de verzekerden bij een bepaalde zorgverzekeraar.

56 Met dien verstande dat, indien de zorgverzekeraar deel uitmaakt van een groep als bedoeld in art. 2:24b BW en de vertegenwoordiging tevens verzekerden vertegenwoordigt van zorgverzekeraars die tot dezelfde groep behoren, de vertegenwoordiging bestaat uit representatieve vertegenwoordigers van de verzekerden van alle betrokken zorgverzekeraars. Zie paragraaf 4.2.

57 Concept-MvT, p. 12.

58 Zie Y. Schothorst, De rol van ledenraden in de governance van zorgverzekeraars, Amsterdam 2014, p. 5 voor de samenstelling van ledenraden.

59 Concept-MvT, p. 12.

60 Concept-MvT, p. 6. Zie Schothorst, 2014, p. 5. 
die aan de leden van de vertegenwoordiging worden gesteld. ${ }^{61}$ Hiermee wordt ook de onafhankelijkheid van de leden geborgd. ${ }^{62} \mathrm{Ik}$ vraag mij af of de woorden 'draagt de zorgverzekeraar er zorg voor' niet te veel vrijheid geven. ${ }^{63}$ Uit de Concept-MvT blijkt niet waarom voor deze woorden is gekozen. ${ }^{64}$ Het belang van openbare werving is genoemd in het IBMG-rapport. ${ }^{65}$

In de praktijk zullen desalniettemin meer onderwerpen dan de wijze waarop de vacature openbaar moet worden gemaakt dienen te worden geregeld. ${ }^{66}$ De vraag is dan ook waarom niet wordt aangeknoopt bij een deel van artikel 2 lid 2 onderdeel a Wmcz, waarin staat dat het aantal leden, de wijze van benoeming, welke personen tot lid kunnen worden benoemd en de zittingsduur van de leden, schriftelijk geregeld moeten worden. ${ }^{67}$ Dit levert geen extra regeldruk op. Voor het goed functioneren van de permanente vertegenwoordiging zal dit toch moeten worden vastgelegd. ${ }^{68}$ Deze schriftelijke regeling dient uiteindelijk ook de instemming van de permanente vertegenwoordiging te krijgen. In het Voorontwerp zou de tekst van de Wmcz nog kunnen worden aangepast, het dient te gaan om 'de openbare wijze van benoeming'.

\section{- Voorzieningen}

De zorgverzekeraar draagt er zorg voor dat de vertegenwoordiging gebruik kan maken van de voorzieningen die zij redelijkerwijs nodig heeft voor de vervulling van haar taak, zo staat in artikel 28b lid 2 onderdeel b Zvw (nieuw). Te denken valt aan een communicatiekanaal via de website van de zorgverzekeraar of andere materiële middelen, aldus de Concept-MvT. ${ }^{69}$ Hoewel zowel de WOR als de Wmcz een soortgelijke verplichting bevatten, wordt deze in dit Voorontwerp anders geformuleerd. ${ }^{70} \mathrm{Ik}$ vraag mij af waarom niet is gekozen voor een van beide bepalingen. Aangezien de Wmcz geen expliciet recht kent op facilitaire ondersteuning, zou in mijn ogen moeten worden aangeknoopt bij de WOR. ${ }^{71} \mathrm{Er}$ zou dan moeten staan: 'De zorgverzekeraar is verplicht het gebruik toe te staan van de voorzieningen die de vertegenwoordiging voor de vervulling van haar taak redelijkerwijze nodig heeft.'

\section{- Kosten}

Tot slot draagt de zorgverzekeraar er op grond van artikel 28b lid 2 onderdeel c Zvw (nieuw) zorg voor dat wordt voorzien in de kosten die noodzakelijk zijn voor de vervulling van de taak van de vertegenwoordiging, waaronder de kosten die verband houden met

61 Concept-MvT, p. 13.

62 Concept-MvT, p. 6.

63 Dit geldt ook voor onderdeel b en c.

64 De Wmcz gebruikt deze woorden niet. De WOR kent deze woorden wel in art. 11 WOR en art. 21 WOR.

65 IBMG 2016, p. 24.

66 Vgl. A.H.G. Wilod Versprille, 'Modellen, mogelijkheden en valkuilen bij het opstellen van statuten aan de hand van het Voorontwerp Wet bestuur en toezicht rechtspersonen', TvOB 2016, p. 37.

67 Dit komt te staan in art. 3 lid $2 \mathrm{Wmcz}$ (nieuw).

68 Voor de ledenraden op grond van Boek 2 BW geldt dat onder andere de wijze van verkiezing in de statuten moet staan, zie art. 2:39 lid $1 \mathrm{BW}$.

69 Concept-MvT, p. 13.

70 Vgl. art. 2 lid 2 onderdeel b Wmcz en art. 17 WOR.

71 Dit wijzigt met de nieuwe Wmcz. Zie art. 6 lid $1 \mathrm{Wmcz}$ (nieuw). 
scholing, onafhankelijke ondersteuning en het voeren van eventuele rechtsgedingen in verband met handhavingsverzoeken. ${ }^{72}$ In mijn ogen benadrukt de WOR meer de plicht en laat minder ruimte voor discussie. Er zou dan moeten staan: 'De kosten die redelijkerwijze noodzakelijk zijn voor de vervulling van de taak van de vertegenwoordiging komen ten laste van de zorgverzekeraar. ${ }^{73}$ In de MvT of eventueel in de wettekst kan de genoemde niet-limitatieve opsomming worden genoemd dan wel worden toegevoegd. Bij voorkeur wordt er met een jaarlijks budget voor scholing en ondersteuning gewerkt en bij rechtsgedingen is gewenst dat de zorgverzekeraar vooraf in kennis wordt gesteld van de verwachte kosten. ${ }^{74}$

Bij het voorzien in kosten die verband houden met scholing gaat het volgens de ConceptMvT om het financieren van een introductietraject of het toekennen van een opleidingsbudget. Leden van de permanente vertegenwoordiging moeten voldoende deskundig zijn met betrekking tot met name het zorginkoopbeleid, waarover zij zullen adviseren. Dit is van belang voor het effectief functioneren van een permanente vertegenwoordiging. ${ }^{75}$ Het lijkt er niet op dat op grond van deze bepaling de permanente vertegenwoordiging deskundigen kan inschakelen op kosten van de zorgverzekeraar. ${ }^{76}$ Indien dit het geval is, is dit dan een bewuste keuze? Betaling van de kosten van het inschakelen van een deskundige kan volgens mij wenselijk zijn, bijvoorbeeld als het gaat om toetsing van financiële onderbouwingen of zaken van medische aard.

De permanente vertegenwoordiging dient te beschikken over een secretaris die onafhankelijk van het bestuur (zowel van de zorgverzekeraar als van het concern) functioneert, aldus de Concept-MvT. ${ }^{77}$ IBMG was al tot de conclusie gekomen dat de materiële ondersteuning van de medezeggenschap goed geregeld moet zijn. ${ }^{78}$

\section{- Informatie}

De zorgverzekeraar verstrekt de (permanente) vertegenwoordiging tijdig en, desgevraagd, schriftelijk alle inlichtingen en gegevens die zij voor de vervulling van haar taak redelijkerwijs nodig heeft, zo staat in artikel 28b lid $3 \mathrm{Zvw}$ (nieuw). Vanzelfsprekend dient dat op een zodanig tijdstip te gebeuren dat de (permanente) vertegenwoordiging voldoende tijd heeft om de informatie te gebruiken voor haar taken, aldus Concept-MvT. ${ }^{79}$ Deze bepaling staat ook in de Wmcz en in de WOR. ${ }^{80}$ Een geheimhoudingsplicht zoals is opgenomen in artikel 20 WOR wordt kennelijk niet nodig geacht. De vraag is of deze keuze terecht is. In geval van vertrouwelijke informatie kan het van belang zijn dat de zorgverzekeraar vrijuit met de permanente vertegenwoordiging kan overleggen.

72 Het gaat om verzoeken bij de NZa, ter handhaving van art. 28a Zvw (nieuw) en art. 28c lid 1, 2 en 4 Zvw (nieuw).

73 Vgl. art. 22 WOR. Zie ook art. 6 lid $2 \mathrm{Wmcz}$ (nieuw).

74 Zie art. 2 lid $4 \mathrm{Wmcz}$ en art. $22 \mathrm{WOR}$.

75 Concept-MvT, p. 6. Concept-MvT, p. 13.

76 Vgl. art. 16 WOR.

77 Concept-MvT, p. 13.

78 IMBG 2016, p. 31. Zie ook motie Bouwmeester/Dik-Faber.

79 Concept-MvT, p. 13.

80 Art. $5 \mathrm{Wmcz}$ en art. $31 \mathrm{WOR}$. De tekst van art. $5 \mathrm{Wmcz}$ komt te staan in art. $10 \mathrm{Wmcz}$ (nieuw). 


\section{- Verantwoording}

De zorgverzekeraar stimuleert dat de (permanente) vertegenwoordiging de verzekerden bij de zorgverzekeraar over haar werkzaamheden informeert en raadpleegt, aldus artikel $28 \mathrm{~b}$ lid 4 Zvw (nieuw). Dit kan volgens de Concept-MvT door het beschikbaar stellen van een online platform waarop vertegenwoordiging en verzekerden met elkaar kunnen communiceren of het bieden van de mogelijkheid tot enquêtering van de achterban. Zonder die informatie kan de vertegenwoordiging haar achterban immers niet in voldoende mate vertegenwoordigen, is de gedachte. ${ }^{81}$ Hoewel de intentie achter deze bepaling goed is, ${ }^{82}$ laat de formulering van de bepaling mijns inziens te wensen over. Wat houdt juridisch gezien het woord 'stimuleren' in? Dit woord komt zowel in de Wmcz als in de WOR niet voor. ${ }^{83}$ Bij wie zou de verantwoordelijkheid voor deze taak moeten liggen? Mijn voorkeur heeft het aan te knopen bij de WOR: 'De zorgverzekeraar stelt de permanente vertegenwoordiging in staat de verzekerden te raadplegen en te informeren, een en ander voor zover dat redelijkerwijs noodzakelijk is voor de vervulling van de taak van de vertegenwoordiging., ${ }^{84}$ De permanente vertegenwoordiging zou hiertoe niet gestimuleerd hoeven te worden, dit vloeit voort uit haar taak. Zij moet deze taak alleen wel kunnen vervullen. Deze laatste verantwoordelijkheid berust bij de zorgverzekeraar.

\subsubsection{Rechten}

De permanente vertegenwoordiging krijgt twee soorten rechten, een instemmingsrecht en een adviesrecht. Elke zorgverzekeraar wordt verplicht dit in zijn statuten te waarborgen volgens de Concept-MvT. ${ }^{85}$

\section{- Instemmingsrecht}

Ten eerste behoeft op grond van artikel 28a lid 3 Zvw (nieuw) de zorgverzekeraar de instemming van de vertegenwoordiging voor de vaststelling, wijziging of intrekking van de inspraakregeling (zie ook paragraaf 4.1). Met dit recht is het niet de wetgever die bepaalt waaraan de inspraakregeling dient te voldoen, maar zijn het de verzekerden zelf, via de vertegenwoordiging, zo staat in de Concept-MvT. ${ }^{86}$ Dit is een belangrijke versterking van de invloed van verzekerden.

\section{- Adviesrecht}

Ten tweede stelt de zorgverzekeraar de permanente vertegenwoordiging in ieder geval in de gelegenheid advies uit te brengen over de vaststelling, wijziging of intrekking van het

81 Concept-MvT, p. 13. Zie ook Concept-MvT, p. 6.

82 Zie IBMG, 2016, p. 27. Vgl. RVZ 2014, p. 29.

83 Wel in art. 5 lid $3 \mathrm{Wmcz}$ (nieuw).

84 Vgl. art. 17 WOR.

85 Concept-MvT, p. 5.

86 Concept-MvT, p. 5 en 12. De vertegenwoordiging kan zelf beoordelen welke wijze van inspraak zij gewenst vindt en de regeling daarop toetsen. Een voor de hand liggend toetsingspunt is of de zorgverzekeraar in de opgestelde regeling voldoende rekening houdt met de diversiteit van verzekerden in de verzekerdenpopulatie. Hiervoor is het noodzakelijk dat de zorgverzekeraar verschillende inspraakinstrumenten hanteert, zodat alle verzekerden daadwerkelijk de gelegenheid krijgen om hun meningen en wensen over het beleid kenbaar te maken. De vertegenwoordiging zal er ook op kunnen letten dat voor het vastleggen of wijzigen van het zorginkoopbeleid ten minste inspraak is geboden aan de verzekerden die de desbetreffende zorg ontvangen. 
jaarlijkse zorginkoopbeleid, aldus artikel 28c lid $1 \mathrm{Zvw}$ (nieuw). Voor deze formulering is volgens de Concept-MvT gekozen, omdat het niet wenselijk is dat de zorgverzekeraar de permanente vertegenwoordiging over technische zaken en details om advies dient te vragen. ${ }^{87}$ Het jaarlijkse zorginkoopbeleid betreft in de praktijk het document dat de zorgverzekeraar jaarlijks uiterlijk 1 april moet publiceren. ${ }^{88}$ Het adviesrecht wordt bewust niet wettelijk verankerd ten aanzien van het algehele beleid van de zorgverzekeraar. ${ }^{89}$

Het LSR, het landelijk steunpunt voor (mede)zeggenschap, is voorstander van uitbreiding van het adviesrecht. ${ }^{90}$ Het adviesrecht dient in de ogen van het LSR ook te zien op de klachten-en geschillenregeling van de zorgverzekeraar; het beleid en informatieverstrekking omtrent opzeg- en overstapmogelijkheden; het beleid aangaande wachttijden en wachtlijsten en het beleid rondom transparantie/openbaarheid van tarieven en gecontracteerde zorg. ${ }^{91}$ In de Concept-MvT staat dat de zorgverzekeraar vrij is de (permanente) vertegenwoordiging ook ten aanzien van andere onderwerpen een adviesbevoegdheid toe te kennen, zoals ten aanzien van bepaalde andere aspecten van het algemene beleid. Dit kan de zorgverzekeraar doen door dit in de statuten neer te leggen. ${ }^{92}$ De vraag is in hoeverre hiervan gebruik zal worden gemaakt. Ik sluit nadere toevoegingen tijdens het wetgevingsproces dan ook niet uit. Een opsomming kan worden vormgegeven zoals artikel $3 \mathrm{Wmcz}$ of artikel 25 WOR. ${ }^{93}$

Ook kan de zorgverzekeraar de vertegenwoordiging in de statuten de bevoegdheid toekennen om ongevraagd te adviseren, zo oppert de Concept-MvT. ${ }^{94}$ De positie van de verzekerden wordt in mijn ogen nog meer versterkt indien de Zvw een bepaling gaat bevatten dat de (permanente) vertegenwoordiging de zorgverzekeraar ongevraagd mag adviseren. Waarom mogen een cliëntenraad en een ondernemingsraad dit wel en een permanente vertegenwoordiging in de vorm van een verzekerden-/ledenraad niet, zo vraag ik mij af. ${ }^{95}$

Het advies wordt op een zodanig tijdstip gevraagd dat het van wezenlijke invloed kan zijn op het jaarlijkse zorginkoopbeleid, zo staat in artikel 28c lid $2 \mathrm{Zvw}$ (nieuw). ${ }^{96}$ Advisering dient plaats te vinden in de vroege fase van de totstandkoming van het beleid en niet als het concept-beleid al gereed is. ${ }^{97}$ Het niet tijdig advies vragen kan niet alleen een grond zijn

87 Concept-MvT, p. 13.

88 Concept-MvT, p. 5 en p. 13.

89 Zie voor de veelal praktische redenen, Concept-MvT, p. 6.

90 De motie Bouwmeester/Dik-Faber spreekt over zeggenschap over dienstverlening en kwaliteitsbeleid.

91 www.hetlsr.nl/intern/753/53/LSR-wetsvoorstel-invloed-verzekerden-positieve-impuls-maar-mist-nogcruciale-thema-s/.

92 Concept-MvT, p. 14.

93 Vgl. art. $7 \mathrm{Wmcz}$ (nieuw).

94 Concept-MvT, p. 13/14.

95 Art. 3 lid $3 \mathrm{Wmcz}$ en art. 23 lid 3 WOR. Zie art. 5 lid $2 \mathrm{Wmcz}$ (nieuw).

96 Vgl. art. 3 lid $2 \mathrm{Wmcz}$. De bewoordingen van art. 7 lid $2 \mathrm{Wmcz}$ (nieuw) luiden anders.

97 Concept-MvT, p. 14. 
voor het gelasten van een enquêteonderzoek door de Ondernemingskamer, maar kan zelfs een grond zijn voor het oordeel wanbeleid. ${ }^{98}$

De (permanente) vertegenwoordiging brengt schriftelijk advies uit en betrekt daarin de uitvoering van de inspraakregeling ${ }^{99}$ en hetgeen is gedaan met de resultaten van de inspraak in het zorginkoopbeleid, zo staat in artikel 28c lid 3 Zvw (nieuw). De permanente vertegenwoordiging dient te beoordelen of de verzekerden betrokken zijn op de wijze zoals vastgelegd in de inspraakregeling, en of er blijkens het concept-zorginkoopbeleid voldoende is gedaan met deze inbreng van verzekerden, aldus de Concept-MvT. ${ }^{100}$ Dit zou volgens mij niet moeten betekenen dat de permanente vertegenwoordiging hierdoor (mede) verantwoordelijk is voor een goede uitvoering van de inspraakregeling van artikel 28a Zvw (nieuw). Deze verantwoordelijkheid ligt vooral bij de zorgverzekeraar. Indien de inspraakregeling niet goed wordt uitgevoerd, heeft het in mijn ogen geen zin dat de permanente vertegenwoordiging op dat moment haar advies weigert te geven. Ook zonder dit advies kan de zorgverzekeraar zijn beleid vormgeven. Verstandiger is om in het advies de mogelijkheden tot verbetering te noemen.

De zorgverzekeraar doet van de vaststelling, wijziging of intrekking van het jaarlijkse zorginkoopbeleid schriftelijk, en voor zover van het advies wordt afgeweken onder opgave van redenen, mededeling aan de (permanente) vertegenwoordiging, aldus artikel 28c lid $4 \mathrm{Zvw}$ (nieuw). Kortom, er mag alleen gemotiveerd worden afgeweken van het advies. Indien de zorgverzekeraar dit niet doet, kan de permanente vertegenwoordiging een handhavingsverzoek doen bij de NZa. ${ }^{101} \mathrm{Ik}$ vraag mij af waarom er niet voor is gekozen om een verplicht overleg tussen de permanente vertegenwoordiging en de zorgverzekeraar in de Zvw vast te leggen. ${ }^{102}$ Dit zorgt ervoor dat er naar elkaar (en de argumenten) wordt geluisterd. Hiermee wordt de gewenste dialoog bevorderd.

- Benoeming raad van commissarissen

Het Voorontwerp bevat geen bepaling waarin de permanente vertegenwoordiging de bevoegdheid krijgt de leden van de raad van commissarissen bij zorgverzekeraars te benoemen. ${ }^{103}$ Hiervan wordt afgezien omdat de ledenraad en de algemene vergadering van aandeelhouders op grond van Boek 2 BW al deze bevoegdheid hebben. Daarnaast wil het Voorontwerp niet ingrijpen in de governancestructuur van zorgverzekeraars. ${ }^{104}$ Ook speelt mee dat deze bevoegdheid als een formele aangelegenheid wordt beschouwd, waaraan minder behoefte is. Daarbij komt dat de benoemingsprocedures volgens de Concept-

98 Zie bijvoorbeeld voor zorginstellingen: Hof Amsterdam (OK) 29 april 2010, ECLI:NL:GHAMS:2010: BM3172, JOR 2010/187 (Zorgcentra De Betuwe); Hof Amsterdam (OK) 20 mei 2010, ECLI:NL:GHAMS: 2010:BM9903, JOR 2010/188, m.nt. L.G. Verburg (Sherpa) en Hof Amsterdam (OK) 2 november 2015, ECLI:NL:GHAMS:2015:4454, JOR 2016/61 (Meavita) m.nt. P. van Schilfgaarde.

99 Zie art. 28a lid 1 Zvw (nieuw).

100 Concept-MvT, p. 6.

101 Art. 83 en art. $86 \mathrm{Wmg}$, zie verder paragraaf 5.

102 Vgl. art. 4 Wmcz. Zie art. 7 lid 4 Wmcz (nieuw).

103 In de motie Kuiper c.s. wordt gevraagd om invloed die bestaat uit medezeggenschap over de samenstelling van de raad van toezicht van de zorgverzekeraar.

104 Commissarissen bij de holding van een concern zijn vaak dezelfde personen als de commissarissen bij de afzonderlijke zorgverzekeraars. Er is geen aanleiding om hieraan afbreuk te doen. Concept-MvT, p. 6. 
MvT zorgvuldig verlopen. ${ }^{105}$ Met de genoemde redenen is goed te verdedigen waarom wordt afgezien van een bevoegdheid tot benoeming van commissarissen.

De cliëntenraad heeft op grond van de Wmcz een bindend voordrachtsrecht bij de benoeming van een van de leden van de raad van toezicht van een zorginstelling. ${ }^{106}$ Hoewel de minister van VWS al kenbaar heeft gemaakt dat zij dit voordrachtsrecht voor de cliëntenraad wil behouden, ${ }^{107}$ bestaat er discussie over dit recht. ${ }^{108}$ Een optie zou kunnen zijn om de permanente vertegenwoordiging (indien er geen ledenraad is) invloed te geven op de profielschets van de raad van commissarissen. ${ }^{109}$ In de profielschets kan de permanente vertegenwoordiging laten opnemen dat een lid van de raad van commissarissen met voldoende kennis van de complexe zorgsector gewenst is. ${ }^{110}$ Op deze kennis wordt in het kader van de Wet op het financieel toezicht (Wft) niet getoetst. ${ }^{111}$

\section{- Recht van enquête}

Het Voorontwerp kent het recht van enquête niet toe aan de permanente vertegenwoordiging. Uit de Concept-MvT blijkt niet of hierover is nagedacht. Ik vermoed dat dit recht niet aan de permanente vertegenwoordiging is toegekend omdat leden bij een vereniging, coöperatie en OWM hiertoe al bevoegd zijn. ${ }^{112}$ Dit betekent wel dat bij zorgverzekeraars met de rechtsvorm nv verzekerden niet een enquêteprocedure kunnen starten. Weliswaar zijn aandeelhouders bij een nv bevoegd tot het indienen van een enquêteverzoek, maar de kans zal niet groot zijn dat zij daartoe voldoende aanleiding zien als het gaat om onderwerpen die betrekking hebben op verzekerden. Wellicht kan in de MvT hieraan aandacht worden besteed. Aan een cliëntenraad kan (in geval van een vereniging of stichting) naar huidig recht in de statuten de bevoegdheid om een enquête te verzoeken toegekend zijn. ${ }^{113}$ Op grond van de nieuwe Wmcz kunnen cliëntenraden bij andere rechtsvormen, zoals een bv, straks ook een enquêteprocedure starten 'omdat de afhankelijkheid van cliënten in alle rechtsvormen gelijk is.'. ${ }^{114}$ Dit geldt ook voor verzekerden bij zorgverzekeraars.

\section{Toezicht en handhaving}

Wie heeft tot taak toezicht te houden op de uitvoering van de nieuwe bepalingen in de Zvw en wie is verantwoordelijk voor de handhaving daarvan?

\footnotetext{
105 Concept-MvT, p. 6-7.

106 Art. 7 lid 2 Wmcz. Art. 11 lid $2 \mathrm{Wmcz}$ (nieuw) is gelijkluidend.

107 Kamerstukken II 2015/16, 31765, 209, p. 3.

108 IBMG 2016, p. 27 is geen voorstander van de bindende voordracht van cliëntenraden bij zorginstellingen.

109 Zie ook IBMG 2016, p. 28.

110 Zie RVZ 2014, p. 22 en p. 24.

111 Zie art. 3:8 en art. 3:9 Wft. Zorgverzekeraars zijn schadeverzekeraars in de zin van de Wft.

112 Art. 2:346 BW.

113 Art. 6.2 UB WTZi.

114 Art. $9 \mathrm{Wmcz}$ (nieuw) en Concept-MvT, paragraaf 6.6.
} 
Intern toezicht door raad van commissarissen

Gezien de taak van de raad van commissarissen op grond van Boek 2 BW om intern toezicht te houden op het bestuursbeleid, ${ }^{115}$ betekent dit volgens de Concept-MvT dat de raad van commissarissen erop zal moeten toezien dat de zorgverzekeraar de inspraakregeling niet eerder vaststelt dan nadat de vertegenwoordiging van verzekerden hiermee heeft ingestemd en dat de inspraakregeling na vaststelling daadwerkelijk wordt uitgevoerd. Daarnaast dient de raad van commissarissen er toezicht op te houden dat de permanente vertegenwoordiging representatief is voor de verzekerdenpopulatie en dat deze haar adviesrecht ten aanzien van het jaarlijkse zorginkoopbeleid kan uitoefenen, zo staat in de Concept-MvT. ${ }^{116}$

\section{Extern toezicht $\mathrm{NZa}$}

Momenteel oefent de NZa toezicht uit op zorgverzekeraars op grond van de Wet marktordening gezondheidzorg (Wmg). ${ }^{117}$ De nieuwe wettelijke bepalingen vragen een meer uitgebreid toezicht, zo staat in de Concept-MvT. De taak van de NZa wordt de statuten van zorgverzekeraars te controleren of daarin aan de permanente vertegenwoordiging het adviesrecht en het instemmingsrecht is toegekend. Daarnaast zal de NZa moeten nagaan of verzekeraars hun verzekerden daadwerkelijk inspraak hebben gegeven op hun beleid. ${ }^{118}$ Indien zorgverzekeraars niet aan de nieuwe eisen voldoen, kan de $\mathrm{NZa}$ een last onder dwangsom of een bestuurlijke boete opleggen. ${ }^{119}$ Betekent dit dat de NZa vooral controleert of alles 'op papier' goed geregeld is? De vraag is dan of dit voldoende is.

\section{Geschillencommissie of rechter?}

Uit het Voorontwerp (of Concept-MvT) blijkt niet of er een geschillencommissie of -regeling komt die bij geschillen over de interpretatie van de nieuwe bepalingen uit de Zvw of de uitvoering daarvan tussen verzekerden en de zorgverzekeraar een oordeel kan geven. ${ }^{120}$ Kunnen verzekerden naar de Geschillencommissie ${ }^{121}$ (die onderdeel uitmaakt van de Stichting Klachten en Geschillen Zorgverzekeringen) of de kantonrechter? Op z'n minst zouden in de MvT daaraan enige woorden moeten worden gewijd. Pas als sprake is van een goede nalevingsprocedure nemen de verzekerden een sterke(re) positie in ten opzichte van de zorgverzekeraar.

115 Een van de taken is het toezien op de naleving van de medezeggenschapsregels. Zie Hof Amsterdam (OK) 2 november 2015, ECLI:NL:GHAMS:2015:4454, JOR 2016/61 (Meavita) m.nt. P. van Schilfgaarde.

116 Concept-MvT, p. 10. Zie over de rol van de raad van commissarissen, RVZ 2014, p. 24 en p. 26 en IBMG 2016, p. 31.

117 Art. 16 onderdeel b Wmg. Bij ministeriële regeling op grond van art. $24 \mathrm{Wmg}$ zal worden geregeld dat de invloed van verzekerden onderdeel uitmaakt van de jaarlijkse rapportage van de NZa.

118 Concept-MvT, p. 10.

119 Art. 83 lid 1 en art. 86 lid 1 Wmg.

120 Zie art. $10 \mathrm{Wmcz}$ en art. $36 \mathrm{WOR}$. Vgl. art. $12 \mathrm{Wmcz}$ (nieuw).

121 Art. $114 \mathrm{Zvw}$. 


\section{Conclusie}

Met het Voorontwerp wordt de invloed van verzekerden in elk geval versterkt. Belangrijk daarbij is hoe de 'onderhandelingen' over de inspraakregeling gaan verlopen. Wordt het in de praktijk een minimumregeling of wordt aan verzekerden voldoende invloed toegekend? Als duidelijk is hoe het een en ander in schriftelijke regelingen wordt uitgewerkt kan pas worden beoordeeld of de invloed van de verzekerden daadwerkelijk wordt versterkt. De instemmingsbevoegdheid van de permanente vertegenwoordiging geeft hierbij enige zekerheid. De Wet verzekerdeninvloed biedt alleen de noodzakelijke randvoorwaarden.

Op sommige punten, zoals het in de Zvw vastleggen van het recht van initiatief en het recht van overleg, kan de positie van verzekerden in mijn ogen eenvoudig worden versterkt. Mijn aanbeveling is ook nogmaals goed te kijken naar de gekozen formuleringen van met name de werkwoorden 'draagt er zorg voor' en 'stimuleert'. Een ander punt is of de naleving voldoende is doordacht. Het adviesrecht zal alleen een versterking van de positie van de verzekerden in de vorm van de permanente vertegenwoordiging zijn, als zorgverzekeraars niet (te veel) van deze adviezen afwijken omdat niet nader wordt getoetst of de afwijking terecht is.

Gezien de mogelijkheden tot invloed op het beleid van een zorgverzekeraar die aan de verzekerden en aan de permanente vertegenwoordiging worden toegekend, creëert de nieuwe Wet verzekerdeninvloed hiermee, naast de WOR en de Wmcz, een nieuwe vorm van medezeggenschap. 